\title{
EPIDEMIOLOGY AND CONTROL OF VIOLET ROOT ROT OF CARROTS
}

\author{
L-H. CHEAH and B.B.C. PAGE \\ New Zealand Institute for Crop \& Food Research Limited \\ Private Bag 11 600, Palmerston North, New Zealand
}

\begin{abstract}
Violet root rot of carrots, caused by Helicobasidium purpureum (anamorph Rhizoctonia crocorum), has caused production losses for many carrot growers in Ohakune over the past three years. During winter, $H$. purpureum produces thick pinkish mycelial mats covering the soil surface. The pathogen survives winter in these mycelial mats and causes infection in new crops. Three field trials at Ohakune showed that soil fumigation with metam gave some control of the disease. Fumigation with calcium cyanamide and soil incorporation of fungicides were not effective in controlling the disease. All commercial carrot cultivars were susceptible to violet root rot. Control measures should rely on disease management strategies which involve cultural practices and prevention of spread of the disease.
\end{abstract}

Keywords: Carrots, fungicides, Helicobasidium purpureum, Rhizoctonia crocorum, soil fumigation, violet root rot.

\section{INTRODUCTION}

Fresh carrots have become a promising export crop to Asia. Export value has risen from \$1.0 million in 1993 to about \$5.0 million in 1996. Violet root rot of carrots (caused by Helicobasidium purpureum Pat.) has become a major problem for carrot growers in the Ohakune region (central North Island) of New Zealand. Leaves of infected plants become chlorotic and die. Infection in a crop starts with small patches which increase in size. Lesions on infected roots are first purplish in colour and then turn cinnamon-brown. If infected roots are pulled out of the ground, abnormally large masses of soil cling to the surfaces of the root lesions.

Violet root rot was first reported 5 years ago in the Ohakune region and since then has caused serious economic losses (Cheah et al. 1998). During the last two years some crops have not been harvested due to severe infection and also out of concern that inoculum may spread to healthy ground. The Fresh Vegetable Committee of the New Zealand Potato Growers' Federation (VegFed) has identified strategies for controlling violet root rot as a priority for research. For this reason, and because the area concerned comprises some 1000 ha of growing land, it is urgent that the control measures applicable to the disease are developed. To date, there is little information on biology and epidemiology of the pathogen or on chemical control. In the past, metam has been used to control nematodes, soilborne fungi, insects and weed seeds in carrots (Shurtleff et al. 1983). Calcium cyanamide has also been shown to be effective in the control of clubroot of brassicas (Cheah 1995).

The objective of this project was to carry out field surveys and three field trials to evaluate the efficacy of two soil fumigants (metam and calcium cyanamide) and other chemicals for the control of violet root rot in carrots.

\section{Epidemiological study}

\section{MATERIALS AND METHODS}

Field surveys were carried out to study the epidemiology (survival and spread) of the pathogen on infected carrot crops over the 1996/97 and 1997/98 seasons. Observations on the pathogen during and after cropping were recorded. 


\section{Field trials}

Two trials were carried out in violet root rot-infested ground at the properties of S. Pearson and R. Wilson, Ohakune. Soil was cultivated thoroughly in November 1996 and a temperature of $20^{\circ} \mathrm{C}$ was recorded at a depth of $10 \mathrm{~cm}$.

Field plots were $75 \mathrm{~m}$ long by $0.8 \mathrm{~m}$ wide. Two rates of metam fumigant, one of calcium cyanamide and an untreated control were included (Table 1). A randomised block layout with four replications was used.

Metam (Fumasol) was boom sprayed onto individual plots and immediately rotary hoed into the ground. The fumigation boom was attached to the front of the rotary hoe and the fluid was pumped through the spray system. TK1.5 jets with a 12 volt deflo jet pump unit were used and run at $140 \mathrm{kPa}$. The tractor forward speed was $2 \mathrm{kph}$ and gave a calculated coverage of 600 litres/ha. The second metam treatment at 1200 litres/ha was obtained by a double pass. The calcium cyanamide (Perlka) was applied with a low spreader to a calculated rate of $400 \mathrm{~kg} / \mathrm{ha}$ (Table 1). The plot was rotary hoed immediately after the application. Control plots were untreated.

Carrots (cultivar Bolero) were seeded with a mechanical drill in a $20 \mathrm{~cm}$-wide band on raised beds. Two rows were planted in each bed. Crop management followed routine commercial practice.

A third field trial to evaluate seven soil fungicides (Table 3) was established at $\mathrm{Mr}$ Young's property ( soil $\mathrm{pH}=6.3$ ) in Ohakune on 18 November 1997, on land known to be heavily infested with violet root rot. The soil was thoroughly cultivated. Fungicide treatments were prepared as suspensions to give the desired concentrations, and were then band sprayed onto the soil surface on each trial plot. The plots were rotary hoed to a depth of about $12 \mathrm{~cm}$ to incorporate chemicals into the soil. Seeds of carrot (cv. Bolero) were then sown with a mechanical sower into the trial plots. Each plot consisted of three rows $10 \mathrm{~m}$ long with $0.8 \mathrm{~m}$ between rows. The experimental design was a randomised block with six replications for each treatment.

Disease assessment was made on 11 May 1998 by visual scoring (1=healthy leaves, $5=$ completely dead) of the top leaves and assessing the below ground roots. For root assessment, three $1 \mathrm{~m}$ plots were manually dug in random positions along each row. Carrots were washed, graded and sorted into diseased and healthy roots. The weight of each category was recorded.

Data were analysed with analysis of variance using the Genstat statistical package.

\section{Epidemiological study}

\section{RESULTS}

Field observations showed that during winter and spring, H. purpureum grew from infected carrots and produced thick pinkish mycelial mats on the soil surface. These mycelial mats may join with the adjacent mats to form a large mat covering the soil surface and can be seen throughout the winter and spring period. Fragments $(3-4 \mathrm{~cm})$ of these mats remained in the soil despite the fact that the soil had been ploughed and rotary hoed. The fungus was easily isolated from these fragments. It is therefore presumed that the fungus can survive over winter as thick mycelial fragments, and that these cause infection in the following carrot crop.

Overseas, it has been reported that the fungus survives as sclerotia in the soil, but in New Zealand, sclerotia have not been observed.

It has been reported that $H$. purpureum has a wide host range of up to 160 species of plants including weeds (Valder 1958). In New Zealand only three crops (carrots, potatoes and beets) have been recorded as host plants. In the absence of carrot plants, the fungus may survive on other hosts.

In the field, infection did not occur until the plants were about 8 weeks old. Symptoms were not usually apparent in crops until late in the growing season. Thus if an infected crop is left in the ground after reaching maturity there is a possibility of total loss, whereas if the roots are harvested immediately they can escape infection. 


\section{Field trials}

Disease assessment at Pearson's block

None of the fumigation treatments reduced $(\mathrm{P}<0.05)$ the incidence of violet root rot in harvested carrots, although metam treatments had about half the level of incidence of the untreated controls (Table 1). Calcium cyanamide gave a higher $(\mathrm{P}<0.05)$ percentage of violet root rot than the metam treatments. There were no significant differences between the two metam rates, nor between the metam treatments and the untreated control.

Metam treatments (treatments 2 and 3$)$ gave higher $(\mathrm{P}<0.05)$ yields than the calcium cyanamide treatment, but none of these treatments gave significantly higher yields than the untreated control.

TABLE 1: Mean percentage of violet root rot and mean yield of carrots after soil fumigation treatments in Pearson's block, Ohakune.

$\begin{array}{lll}\text { Treatment } & \begin{array}{l}\text { Violet root rot } \\ \text { incidence }(\%)\end{array} & \text { Yield (t/ha) }\end{array}$

\begin{tabular}{lcr}
\hline 1. Untreated & 8.4 & 99.7 \\
2. Metam (600 litres/ha) & 3.1 & 114.2 \\
3. Metam (1200 litres/ha) & 4.2 & 110.6 \\
4. Calcium cyanamide (400 kg/ha) & 27.5 & 81.1 \\
LSD (P<0.05, Df $=12)$ & 20.0 & 19.3 \\
\hline
\end{tabular}

\section{Disease assessment at Wilson's block}

Incidence of violet root rot was much higher in the Wilson block (Table 2) than on the Pearson block. There was no indication of any difference between the two rates of metam on disease incidence, with the average being $19.2 \%$. Metam treated plots contained about one third of the violet root found in untreated plots $(\mathrm{P}<0.10)$.

The calcium cyanamide treatment gave a disease incidence similar to that of the untreated plots (Table 2$)$, but higher $(\mathrm{P}<0.05)$ than the average of the two metam treatments.

TABLE 2: Mean percentage of violet root rot of carrots after soil fumigation treatments in Wilson's block, Ohakune.

Treatment Violet root rot

1. Untreated

2. Metam (600 litres/ha)

3. Metam (1200 litres/ha)

4. Calcium cyanamide (400 kg/ha)

LSD $(\mathrm{P}<0.05, \mathrm{Df}=9)$

$(\mathrm{P}<0.10, \mathrm{Df}=9)$
62.4

20.1

18.3

67.4

51.0

41.0

\section{Disease assessment at Young's block}

Analyses of variance showed that there were no significant differences in disease severity scores on leaves between any of the fungicide treatments and the control (data not shown). This indicated that soil incorporation of these fungicides was not effective for control of violet root rot. There were no statistically significant differences in the percentage of healthy roots between any of the fungicide treatments and the untreated control (Table 3). 
TABLE 3: Mean percentage of healthy roots of carrots harvested from field plots in violet root rot-infested soil to which different fungicide treatments had been applied (Young's block).

\begin{tabular}{llllc}
\hline Fungicide & Common name & Trade name & Rate (ai/ha) & Healthy root (\%) \\
\hline 1 & azoxystrobin & Amistar & $1.0 \mathrm{~kg}$ & 70.2 \\
2 & fludioxonil & Celest & 8.3 litres & 70.5 \\
3 & flusulfamide & Nebijin & 1.0 litres & 61.1 \\
4 & hypochlorous acid & Nylate & $200 \mathrm{~kg}$ & 65.1 \\
5 & pencycuron & Monceren & $2.5 \mathrm{litres}$ & 74.8 \\
6 & quitozene & Terraclor & $90 \mathrm{~kg}$ & 72.0 \\
7 & tolclofos-methyl & Rizolex & 10 litres & 73.0 \\
8 & untreated & & & 76.2 \\
LSD $(\mathrm{P}<0.05, \mathrm{Df}=20)$ & & & 20.9 \\
\hline
\end{tabular}

\section{DISCUSSION}

These results showed that soil applications of metam reduced incidence of violet root rot in carrots although it was not always statistically significant. However, calcium cyanamide and other fungicides did not give effective control of the disease. One of the possible explanations for this is that $H$. purpureum produces extensive mycelial mats on the soil surface during winter. We have also seen large fragments of these mats still remaining in the soil despite the soil being ploughed and rotary hoed. Soil fumigation may not be effective in penetrating these mats to kill the pathogen.

It has been shown that violet root rot can be suppressed with high nitrogen levels in the soil (Garrett 1949) or high soil pH (Valder 1958). In this trial, calcium cyanamide was selected because it contains $20 \%$ nitrogen and can increase soil pH as it hydrolyses (Rieder 1981). In one of our trials calcium cyanamide gave a higher disease incidence and lower yields than the nil treatment. This was possibly due to the patchiness of the infection in the field, which led to less precision in the treatment effects than usually occurs in field trials of this size.

The results for metam, although not conclusive in these trials, were encouraging. Where the infestation with $H$. purpureum was very heavy (Wilson's block), the incidence of infested carrots was greatly reduced by both rates of this treatment and this reduction (to less than half the levels of untreated plots) was fairly consistent in both trials where metam was tested. Further work to confirm these results is important.

The observed results in the Wilson's block correspond to an increase in nondiseased yield from under $40 \%$, where no treatment was applied, to about $80 \%$ with metam. This result was achieved with both application rates, so 600 litres/ha would be suitable for this chemical. Lower rates should be tested to determine whether they give useful reductions in the incidence of violet root rot in carrots.

Since most commercial carrot cultivars appear to be susceptible to violet root rot (Dalton et al. 1981) and since no chemicals are completely effective against the disease (Snowdon 1991), the main control measures should involve cultural practices, e.g. crop rotation (with cereals), good soil drainage, early harvesting of crops, and preventing the spread of infested soil (Cheah and Page 1999). It is important to detect the disease before mycelial mats are formed. The disease areas or infected patches should be fenced to prevent the spread of infested soil. The soil should be fumigated with metam before growing other non-host crops, e.g. cereals or grasses. It is also important to remove and destroy the mycelial mats and alternative hosts (e.g. beetroot and potatoes) to prevent build-up and spread of the disease.

\section{ACKNOWLEDGEMENTS}

This research was funded by the New Zealand Vegetable and Potato Growers' Federation Inc. We thank Mr S. Pearson, Mr R. Wilson and Mr N. Young of Ohakune for the use of their land and Dr. Koolaard for statistical analysis. 


\section{REFERENCES}

Cheah, L-H., 1995. Calcium cyanamide $\left(\mathrm{CaCN}_{2}\right)$ for clubroot control in cauliflowers. Proc. $10^{\text {th }}$ Australasian Plant Path. Conf.: 99.

Cheah, L-H., Marshall, J. and Page, B.B.C., 1998. Violet root rot of carrots. N.Z. Commercial Grower 53(4): 21-22.

Cheah, L-H. and Page, B.B.C., 1999. Violet root rot of carrots: disease management strategies. N.Z. Commercial Grower 54(3): 28-29.

Dalton, L.P., Epton, H.A.S. and Bradshaw, N.J., 1981. The susceptibility of modern carrot cultivars to violet root rot caused by Helicobasidium purpureum. J. Hort. Sci. 56: 95-96.

Garrett, S.D., 1949. A study of violet root rot, 2. Effect of substratum on survival of Helicobasidium purpureum colonies in the soil. Trans. Brit. Mycological Soc. 32: 217-223.

Rieder, G., 1981. Calcium cyanamide-fertilizer or pesticide? World Crops 33: 17-20.

Shurtleff, M.C., Edwards, D.I., Courtner, J.W. and Randell, R., 1983. Soil disinfestation - Methods and materials. College of Agriculture, University of Illinois at Urbana - Champaign, Circular 1213. 36 p.

Snowdon, A.L., 1991. Violet root rot of carrots and parsnips caused by Helicobasidium purpureum Pat. p. 385. In: A Colour Atlas of Postharvest Diseases and Disorders of Fruit and Vegetables V2: Vegetable. A.L. Snowdon (Ed.) BPCC Heznell Books, England.

Valder, P.G., 1958. The biology of Helicobasidium purpureum Pat. Trans. Brit. Mycological Soc. 41: 283-308. 